\title{
LEGAL REASONING HAKIM DALAM PENGAMBILAN PUTUSAN PERKARA DI PENGADILAN
}

\author{
Nur Iftitah Isnantiana ${ }^{1}$ \\ ${ }^{1}$ Universitas Muhammadiyah Purwokerto
}

\begin{abstract}
ABSTRAK
Hakim merupakan personifikasi lembaga peradilan, dalam membuat keputusan suatu perkara selain dituntut memiliki kemampuan intektual, juga memiliki moral dan integritas yang tinggi sehingga mencerminkan rasa keadilan, menjamin kepastian hukum dan dapat memberikan manfaat bagi masyarakat. Hakim dalam memutuskan suatu perkara harus didasarkan pada berbagai pertimbangan yang dapat diterima semua pihak dan tidak menyimpang dari kaidah-kaidah hukum yang ada, yang disebut dengan Legal reasoning.

Legal reasoning diartikan sebagai pencarian "reason" tentang hukum atau pencarian dasar tentang bagaimana seorang hakim memutuskan perkara/kasus hokum. Legal reasoning merupakanbagian dari putusan pengadilan dalam memutuskan suatu perkara. Legal reasoning oleh seorang hakim dapat berdasarkan aspek filosofis, yuridis, sosiologis atau teologis yang mencerminkan asas kepastian hukum, keadilan dan kemanfaatan bagi para pihak serta dapat menggunakan beberapa metode penafsiran hukum seperti penafsiran Sistimatis, Historis dan Sosiologis atau Teologis, Komparatif, Antisipatif atau Futuristis, Restriktif, Ekstensif dan atau. A Contrario.

Kesimpulan yang dapat diambil dari telaah tentang Legal reasoning adalah bahwa Legal reasoning juga merupakan hasil ijtihad hakim dalam membuat putusan. Hakim dalam merumuskan dan menyusun pertimbangan hukum atau Legal reasoning harus cermat, sistimatik dan dengan bahasa Indonesia yang benar dan baik. Pertimbangan disusun dengan cermat artinya pertimbangan hukum tersebut harus lengkap berisi fakta peristiwa, fakta hukum, perumusan fakta hukum penerapan norma hukum baik dalam hukum positif, hukum kebiasaan, yurisprodensi serta teori-teori hukum dan lain-lain, mendasarkan pada aspek dan metode penafsiran hukum yang sesuai dalam menyusun argumentasi (alasan) atau dasar hukum dalam putusan hakim tersebut.
\end{abstract}

Kata Kunci: Legal Reasoning, Putusan, Hakim. 


\section{Islãmadîna \\ JURNAL PEMIKIRAN ISLAM}

Volume XVIII, No. 2, Juni $2017:$ 41-56

\section{ABSTRACT \\ LEGAL REASONING OF THE JUDGES DECISION}

Judge was court institutions personification, in the making a decision in a case beside must to have intelectual capability, high moral and integrity too so the result could reflecting justice, law certainly guaranteed and society usefull. Judge in decising a case must be based on the some reason which could accept all person and not avoidance from law norms, its calledLegal reasoning.

The meaning of Legal reasoning was looking for reason about law or based about how a judge decising a law case. Legal reasoning was part of court decision in decising a case. Judge's legal reasoning based on philosophies, juridice, sociologist, or theologist aspec which reflecting certaily law, justice and usefull for all person, and also could used some law interpretation as sistematic, histories, sociologist or theologist, cmparative, futuristic, restrictif and or A Contrario.

The conclusion from Legal reasoning topic, that Legal reasoning was a result of judges ijtihad in the making decision. Judge in formulating and designing legal reasoning must exact, sistematic and use good and right Indonesian language. Legal reasoning must designing exact and detail its means that legal reasoning must have content completely about event fact, law fact, law fact formulation, law norm implementation at law positive, law usually, yurisprodency also law theories and so on, based on law aspect and interpretation which such as the case in designing reason or law based in that judge decision.

Keywords: Legal Reasoning, Judge, Decision. 


\section{PENDAHULUAN}

Hukum Acara Perdata adalah peraturan hukum yang mengatur bagaimana caranya menjamin ditaatinya hukum perdata materiil dengan perantaraan hakim. Apabila ada orang atau beberapa orang yang merasa haknya dilanggar atau menimbulkan kerugian baginya, maka ia dapat mengajukan tuntutan atas haknya melalui pengadilan,(Mertokusumo, 1993: 2). Dengan adanya penyelesaian menggunakan hukum acara perdata diharapkan pihak-pihak yang bersengketa dapat menerima putusan yang akan diambil hakim secara baik. Dalam hukum acara perdata ada beberapa asas-asas (Mertokusumo, 1993: 10-18), sebagai berikut: (a) asas hakim bersifat menunggu, (b) hakim pasif, (c) sifat terbukanya persidangan, (d) mendengar kedua belah pihak (e) putusan harus disertai alasan-alasan, (f) beracara dikenakan biaya, (g) tidak ada keharusan mewakilkan,

Menurut Cik Hasan Bisri (1996: 180), Hakim secara etimologi berarti "orang yang memutuskan hukum". Hakim merupakan unsur utama di dalam pengadilan. Bahkan ia "identik" dengan pengadilan itu sendiri. Kebebasan kekuasaan kehakiman seringkali diidentikkan dengan kebebasan hakim. Demikian halnya, keputusan pengadilan diidentikkan dengan keputusan hakim. Oleh karena itu, pencapaian penegakan hukum dan keadilan terletak pada kemampuan dan kearifan hakim dalam merumuskan keputusan yang mencerminkan keadilan. Menurut Khamimmudin (2010: 66), hakim dalam sistem peradilan kita adalah hakim yang bebas dalam memutuskan perkara, dia tidak dapat dan tidak boleh dipengaruhi oleh siapapun, dia hanya bertanggungjawab kepada hati nuraninya sendiri dan tentunya kepada Tuhan.

Menurut Komisi Hukum Nasional Republik Indonesia (2003: iii), Hakim merupakan personifikasi lembaga peradilan, mengemban amanah yang tidak ringan. Didalam membuat keputusan hakim tidak saja dituntut memiliki kemampuan inteketual, akan tetapi juga diharapkan memiliki moral dan integritas yang tinggi, bahkan pada titik tertentu, hakim juga harus mempunyai tingkat keimanan dan ketaqwaan, mampu berkomunikasi dengan baik, serta dapat menjaga peran, kewibawaan dan statusnya dihadapan masyarakat, sehingga hasil-hasil kerjanya dapat mencerminkan rasa keadilan, menjamin kepastian hukum dan dapat memberikan manfaat bagi masyarakat. Menurut Komisi Yudisial Republik Indonesia (2009: 6), demikian luhur misi yang diemban oleh hakim, sehingga konstitusi (Pasal 24 ayat (1) UUD 1945) dan peraturan perundang-undangan (UU No. 4 Tahun 2004 tentang Kekuasaan Kehakiman jo UU No. 14/1985 jo UU No. 3 Tahun 2009 tentang Mahkamah 


\section{Islãmadîna \\ JURNAL PEMIKIRAN ISLAM}

Volume XVIII, No. 2, Juni $2017:$ 41-56

Agung) meletakkan dasar hukum yang kuat, berkaitan dengan tugas, fungsi dan kedudukan hakim.

Pengambilan keputusan sangat diperlukan oleh hakim atas sengketa yang diperiksa dan diadilinya. Hakim harus dapat mengolah dan memproses data-data yang diperoleh selama proses persidangan, baik dari bukti surat, saksi, persangkaan, pengakuan maupun sumpah yang terungkap dalam persidangan (Lihat Pasal 164 HIR). Sehingga keputusan yang akan dijatuhkan dapat didasari oleh rasa tanggung jawab, keadilan, kebijaksanaan, profesionalisme dan bersifat obyektif. Pada Pasal 5 Undang-Undang No. 48 Tahun 2009 Tentang Kekuasaan Kehakiman, dalam memutus perkara yang terpenting adalah kesimpulan hukum atas fakta yang terungkap dipersidangan. Untuk itu hakim harus menggali nilai-nilai, mengikuti, dan memahami nilai-nilai hukum dan rasa keadilan yang hidup dalam masyarakat. Menurut R. Soeparmono (1946: 146), sumber hukum yang dapat diterapkan oleh hakim dapat berupa peraturan perundang-undangan berikut peraturan pelaksanaannya, hukum tidak tertulis (hukum adat), putusan desa, yurisprudensi, ilmu pengetahuan maupun doktrin/ajaran para ahli.Hakim dalam memutuskan suatu perkara harus didasarkan pada berbagai pertimbangan yang dapat diterima semua pihak dan tidak menyimpang dari kaidah-kaidah hukum yang ada. Legal reasoning diartikan sebagai pencarian "reason" tentang hukum atau pencarian dasar tentang bagaimana seorang hakim memutuskan perkara/kasus hukum, seorang pengacara meng-argumentasi-kan hukum dan bagaimana seorang ahli hukum menalar hukum, Tim Peneliti Komisi Yudisial (2009: 27).

Menurut Sudikno Mertokusumo (2002: 108), bagi para hakim legal reasoning ini berguna dalam mengambil pertimbangan untuk memutuskan suatu kasus. Seorang hakim sebelum menjatuhkan putusannya harus memperhatikan serta mengusahakan seberapa dapat jangan sampai putusan yang akan dijatuhkan nanti memungkinkan timbulnya perkara baru. Putusan harus tuntas dan tidak menimbulkan ekor perkara baru. Tugas hakim tidak berhenti dengan menjatuhkan putusan saja, akan tetapi juga menyelesaikan sampai pada pelaksanaannya. Dalam perkara perdata hakim harus membantu para pencari keadilan dan berusaha sekeras-kerasnya mengatasi segala hambatan dan rintangan untuk dapat tercapainya peradilan yang sederhana, cepat dan biaya ringan.

Legal reasoning hakim menurut Sudikno Mertokusumo (2002: 108) sangat terkait dengan tugas pokok seorang hakim, yaitu bertugas menerima, memeriksa dan mengadili serta menyelesaikan setiap perkara yang diajukan kepadanya, kemudian hakim meneliti perkara dan akhirnya mengadili yang 
berarti memberi kepada yang berkepentingan hak atau hukumnya. Demikian pentingnya legal reasoning seorang hakim dalam memutuskan suatu perkara di pengadilan, oleh karena itu sangat menarik untuk mengetahui tentang legal reasoningdalam pengambilan putusan perkara.

\section{PEMBAHASAN}

Di dalam masyarakat terdapat banyak masalah sosial. Dari sekian banyak masalah-masalah sosial itu kita harus mampu menemukan atau menyeleksi masalah hukumnya, untuk kemudian dirumuskan dan dipecahkan. Bukan pekerjaan yang mudah untuk menyeleksi masalah hukum dari masalah-masalah sosial, yang sering tumpang tindih dengan masalah hukum dan sulit untuk dicari batasnya, seperti misalnya masalah politik, masalah kesusilaan, masalah agama dan sebagainya. Di sinilah pentingnya kemampuan untuk menyeleksi dan kemudian merumuskan masalah hukum (legal problem identification).

Menurut Sudikno Mertokusumo (2002: 192-195), kalau masalah hukumnya telah diketemukan dan dirumuskan, masih perlu diketahui masalah hukum itu masalah hukum bidang apa, hukum perdata, hukum dagang, hukum agraria, hukum pidana, dan sebagainya. Antara masalah hukum perdata dengan masalah hukum pidana sering tidak tajam batasnya, antara ingkar janji, perbuatan melawan hukum dan perbuatan pidana, antara penggelapan dan pencurian.Setelah diketemukan masalah hukumnya dengan menggunakan penemuan hukum, maka harus dicari pemecahannya (legal problem solving). Sehingga dalam mempelajari hukum, dihadapkan pada peristiwa konkret, kasus atau konflik yang memerlukan pemecahan dengan mencari hukumnya. Bekal untuk memecahkan konfik itu adalah pengetahuan tentang norma hukum, sistem hukum dan penemuan hukum. Setelah pemecahan masalah hukum perlu diberi hukumnya, haknya atau hukumannya. Dengan kata lain, harus diambil keputusan (decision making) yaitu berupa putusan hakim. Menurut Sudikno Mertokusumo (2002: 202) Putusan hakim adalah suatu pernyataan yang oleh hakim sebagai pejabat negara yang diberi wewenang untuk itu, diucapkan di persidangan dan bertujuan untuk mengakhiri atau menyelesaikan suatu perkara atau sengketa antara dua pihak. Selain diucapkan, pernyataan putusan juga dituangkan dalam bentuk tertulis dan kemudian diucapkan oleh hakim di persidangan.

Menurut M. Yahya Harahap (2005: 798), Putusan adalah produk dari pemeriksaan perkara yang dilakukan oleh hakim. Berdasarkan Pasal 178 HIR/189 RBG, setelah pemeriksaan selesai, maka hakim karena jabatannya harus melakukan musyawarah untuk mengambil putusan yang akan dijatuhkan. Pemeriksaan dianggap telah selesai apabila telah melalui tahap jawaban dari tergugat, replik dari penggugat, duplik dari tergugat, pembuktian dan 


\section{Islãmadîna \\ JURNAL PEMIKIRAN ISLAM}

kesimpulan yang diajukan oleh para pihak. Pembahasan mengenai cacat tidaknya suatu putusan hakim harus ditinjau dari asas-asas putusan yang harus diterapkan dalam putusan. Pada hakikatnya asas-asas tersebut terdapat dalam Pasal 178 HIR/189 RBG dan Pasal 50 UU No. 48 Tahun 2009 Tentang Kekuasaan Kehakiman, yaitu :

1. Memuat Dasar Alasan yang Jelas dan Rinci

Putusan yang dijatuhkan oleh hakim harus bedasarkan pertimbangan yang jelas dan cukup. Putusan yang tidak memenuhi ketentuan tersebut dikategorikan putusan yang tidak cukup pertimbangan atau onvoldoende gemotiveerd. Alasan yang dijadkan pertimbangan dapat berupa pasal-pasal tertentu peraturan perundang-undangan, hukum kebiasaan, yurisprudensi atau doktrin hukum.

Hal tersebut ditegaskan dalam Pasal 50 UU No. 48 Tahun 2009 Tentang Kekuasaan Kehakiman yang menegaskan bahwasanya Putusan pengadilan selain harus memuat alasan dan dasar putusan, juga memuat pasal tertentu dari peraturan perundang-undangan yang bersangkutan atau sumber hukum tak tertulis yang dijadikan dasar untuk mengadili. Untuk memenuhi kewajiban itulah Pasal 5 UU Kekuasan Kehakiman memerintahkan hakim untuk menggali nilai-nilai, mengikuti, dan memahami nilai-nilai hukum dan rasa keadilan yang hidup dalam masyarakat.

Bertitik tolak dari pasal yang dikemukakan di atas, putusan yang tidak cukup pertimbangan adalah masalah yuridis, akibatnya putusan dapat dibatalkan pada tingkat banding atau kasasi. Begitu pula pertimbangan yang mengandung kontradiksi, putusan demikian tidak memenuhi syarat sebagai putusan yang jelas dan rinci, sehingga cukup alasan menyatakan putusan yang dijatuhkan melanggar asas yang digariskan Pasal 50 UU No. 48 Tahun 2009 Tentang Kekuasaan Kehakiman.

2. Wajib Mengadili Seluruh Bagian Gugatan

Asas kedua yang digariskan oleh Pasal 178 ayat (2) HIR/Pasal 189 ayat (2) RBG dan Pasal 50 RV adalah putusan harus secara total dan menyeluruh memeriksa dan mengadili setiap segi gugatan yang diajukan. Tidak boleh hanya memeriksa dan memutus sebagian saja dan mengabaikan gugatan selebihnya. Cara mengadili yang demikian bertentangan dengan asas yang digariskan oleh undang-undang.

3. Tidak Boleh Mengabulkan Melebihi Tuntutan

Berdasarkan Pasal 178 ayat (3) HIR/Pasal 189 ayat (3) RBG dan Pasal 50 RV, 
putusan tidak boleh mengabulkan melebihi tuntutan yang dikemukakan dalam gugatan. Larangan itu disebut ultra petitum partium. Hakim yang mengabulkan posita maupun petitum gugatan, dianggap telah melampaui batas wewenang atau ultra vires yakni bertindak melampaui wewenangnya. Apabila putusan mengandung ultra petitum, harus dinyatakan cacat (invalid) meskipun hal itu dilakukan hakim dengan itikad baik (good faith) maupun sesuai dengan kepentingan umum (public interest).Mengadili dengan cara mengabulkan melebihi dari apa yang di gugat dapat dipersamakan dengan tindakan yang tidak sah (illegal) meskipun dilakukan dengan itikad baik, seperti dijelaskan oleh M. Yahya Harahap (2005: 801-802).

4. Diucapkan di muka Umum

Persidangan dan putusan diucapkan dalam siding pengadilan yang terbuka untuk umum atau di muka umum merupakan salah satu bagian yang tidak terpisahkan dari asas fair trial. Melalui asas fair trial, pemeriksaan persidangan harus berdasarkan proses yang jujur sejak awal sampai akhir. Prinsip peradilan terbuka untuk umum mulai dari awal pemeriksaan sampai putusan dijatuhkan. Hal itu tentunya dikecualikan untuk perkara tertentu, misalnya perkara perceraian. Akan tetapi walaupun dilakukan dalam persidangan tertutup untuk umum, putusan wajib diucapkan dalam sidang yang terbuka untuk umum.

Pelanggaran terhadap hal di atas ditegaskan dalam Pasal 13 ayat (2) UU Kekuasaan Kehakiman yang berbunyi: "Putusan pengadilan hanya sah dan mempunyai kekuatan hukum apabila diucapkan dalam sidang terbuka untuk umum”.Berdasarkan ketentuan tersebut, maka putusan yang tidak diucapkan di muka umum berakibat putusan batal demi hukum.

Tugas hakim pada dasarnya adalah:

1. Mengkonstatir artinya melihat, mengakui atau membenarkan telah terjadinya suatut peristiwa yang diajukan oleh para pihak yang berperkara. Hakim harus pasti akan konstateringnya, sehingga ia harus pasti akan kebenarannya itu, tidak sekedar dugaan atau kesimpulan yang dangkal atau gegabah tentang adanya peristiwa yang bersangkutan. Selanjutnya hakim harus melakukan pembuktian dengan alat-alat bukti dengan tujuan untukmendapatkan kepastian tentang kebenaran peristiwa yang diajukannya. Dan peristiwa yang telah dikonstatir sebagai peristiwa yang benar-benar terjadi. Kemudian hakim setelah berhasil mengkonstatir peristiwanya tersebut, lalu "mengkualifisir" nya.

2. Mengkualifisir artinya menilai peristiwa yang telah dianggap benar-benar 


\section{Islãmadîna \\ JURNAL PEMIKIRAN ISLAM}

terjadi dengan cara memilih kejadian-kejadian atau peristiwa-peristiwa hukum dari hasil pemeriksaan di persidangan. Selanjutnya hasil penilaian peristiwa hukum tersebut dihubungkan dengan norma hukumnya. Dengan demikian setelah tahapan ini seorang hakim harus dapat menemukan hukumnya terhadap peristiwa yang telah dikonstatirnya.

Hakim setelah mengkonstatir peristiwa atau kejadian berarti hakim tersebut mempunyai "solving legal problems" dan ia wajib mencari solusinya atau jawabannya, memang sebenarnya tidak mudah untuk mendapat jawabanya. Hal ini karenadalam kehidupan di masyarakat terdapat maslah-masalah kehidupan, baik yang berkaitan agama, sosial, moral, kesopanan, kesusilaan dan lain sebagainya. Tetapi hakim sebagai seorang yang mempunyai kompentensi memberikan jawabannya harus dapat menemukan hukumnya. Oleh karena itu hakim sebelumnya harus mampu menyeleksi masalahnya dan kemudian merumuskan hukumnya. Setelah itu baru ia menemukan hukumnya.Setelah menemukan hukum dari peristiwa/kejadian itu seorang hakim harus melakukan pemecahan hukum (legal problems solving).

Dalam menemukan hukum, ditegaskan dalam Pasal 28 Undang-undang Nomor 4 Tahun 2004, bahwa "Hakim wajib menggali, mengikuti dan memahami nilai-nilai hukum dan rasa keadilan yang hidup dalam masyarakat. Kata menggali mengasumsikan bahwa hukumnya itu ada, tetapi tersembunyi, agar sampai pada permukaan masih harus digali. Jadi hukumnya itu ada, tetapi masih harus digali, dicari dan diketemukan, kemudian diciptakan. Menurut Bernard Arif Sidartha (2000: 206), proses-proses pembuatan putusan tidak dapat dilepaskan dari kegiatan bernalar hakim. Kegiatan bernalar dari Hakim dengan beragam motivering yang menopangnya, selalu berada dalam pusaran tarikan keanekaragaman kerangka orientasi berpikir yuridis yang terpelihara dalam sebuah sistem autopoesis, sehingga dapat berkembang menurut logikanya sendiri, dan eksis sebagai sebuah model penalaran yang khas sesuai dengan tugas-tugas profesionalnya. Menurut Tim Penyusun Kamus Besar Bahasa Indonesia (2009), Hakim dalam memutus perkara selain berdasarkan proses seperti tersebut di atas harus berdasarkan argumentasi atau alasan. Sedangkan pengertian "argument" adalah alasan yang dapat dipakai untuk memperkuat atau menolak sesuatu pendapat, Sedangkan agumentasi adalah pemberian alasan untuk memperkuat atau menolak sesuatu pendapat.

Menurut Ranuhandoko (1996: 67) dalam Terminologi Hukum istilah 'argument' diartikan sebagai berusaha mempercayakan orang lain dengan mengajukan alasan-alasan. Selanjutnya menurut Rakhmad Jalaludin (1995: 22-23) dalam Kamus Filsafat 'argument' dari bahasa Latin 'arguere' yang 
berarti menjelaskan. Alasan-alasan (bukti) yang ditawarkan untuk mendukung atau menyangkal sesuatu. Dalam logika, diartikan sebagai serangkaian pernyataan yang disebut premis-premis yang secara logis berkaitan dengan pernyataan berikutnya yang disebut konklusi. Menurut Garner (1999: 102) argumen-argumen dibagi menjadi dua kategori umum, yaitu deduktif dan induktif, dalam Black's Law Dictionary istilah 'argument' diartikan "a statement that attempts to persuase; esp., the remarks of counsel in alalyzing and pointing out or repudiating a desired inference, for the assistance of decision-maker. The act or process of attempting to persuade". Sedangkan 'argumentative', diartikan sebagai "of or relating to argument or persuasion, stating not only facts, but also inferances and conclusions drawn from facts (the judge sustained the prosecutor's objection to the argumentative question)".

Menurut Sudarsono (1992: 36) dalam Kamus Hukum istilah 'argumen' diberikan arti sebagai alasan yang dapat dipakai untuk memperkuat atau menolak suatu pendapat, pendirian, atau gagasan. Berargumen, berarti berdebat dengan saling mempertahankan atau menolak alasan masing-masing. Istilah argumentasi, diartikan sebagai pemberian alasan untuk memperkuat atau menolak suatu pendapat, pendirian atau gagasan. Berargumentasi berarti memberikan alasan untuk memperkuat atau menolak suatu pendapat, pendirian atau gagasan. Menurut Wojowasito S. (2001: 45) dalam Kamus Belanda-Indonesia istilah 'argument' diartikan bukti sanggahan, alasan, perbantahan, dan 'argumentatie' diartikan sebagai hal memberikan alasan dengan cara tertentu, debat, pembahasan. Dalam 'Kamus Inggris-Indonesia' ditemukan istilah 'argument' yang diberikan arti alasan, perdebatan, bukti, perbantahan, dan 'argumentation' diberikan arti sebagai pemberian alasan dengan cara tertentu, debat, pembahasan. Dalam Kamus Bahasa Indonesia, argumen diartikan sebagai alasan berupa uraian penjelasan, dan argumentasi diartikan sebagai pemberian alasan yang diuraikan secara jelas untuk memperkuat suatu pendapat. Dari pengertian-pengertian diatas, diambil simpulan pengertian 'argumentasi' diartikan sebagai, 'mengajukan alasan berupa uraian penjelasan yang diuraikan secara jelas, berupa serangkaian pernyataan yang secara logis berkaitan dengan pernyataan berikutnya yang disebut konklusi, untuk memperkuat atau menolak suatu pendapat, pendirian atau gagasan'. Karena dalam makalah ini berbicara tentang hukum, maka dengan demikian yang dimaksud dengan argument di sini adalah 'argumentasi hukum' yaitu "alasan berupa uraian penjelasan yang diuraikan secara jelas, berupa serangkaian pernyataan secara logis, untuk memperkuat atau menolak suatu pendapat, pendirian atau gagasan, berkaitan dengan asas hukum, norma hukum dan peraturan hukum konkret, serta sistem hukum dan 


\section{Islãmadîna \\ JURNAL PEMIKIRAN ISLAM}

penemuan hukum".

Setiap orang dalam mengemukakan pendapat harus menggunakan argumen yang bahasa sehari-hari disebut "alasan". Demikian juga seorang hakim dalam memutus suatu perkara wajib mengemukakan argumen, baik yang berkaitan dengan pokok perkara maupun cabang perkaranya. Argumen-argumen tersebut harus dirumuskan dan disusun dengan cermat, runtut, sistimatik dengan menggunakan bahasa hukum yang baik dan benar. Kemudian argumen-argumen hukum tersebut dalam putusan hakim disebut pertimbangan hukum atau legal reasoning. Menurut Golding (1984: 1) pengertian legal reasoning digunakan dalam dua arti, yaitu dalam arti luas dan sempit. Dalam arti luas, legal reasoning berkaitan dengan proses psikologi yang dilakukan Hakim, untuk sampai pada keputusan atas kasus yang dihadapinya. Studi legal reasoning dalam arti luas menyangkut aspek psikologi dan aspek biographi.Legal reasoning dalam arti sempit, berkaitan dengan argumentasi yang melandasi satu keputusan. Studi ini menyangkut kajian logika suatu keputusan. Berkaitan dengan jenis-jenis argumentasi, hubungan antara reason (pertimbangan, alasan) dan keputusan, serta ketepatan alasan atau pertimbangan yang mendukung keputusan.

Menyelesaikan masalah hukum secara yuridis dalam intinya berarti menerapkan aturan hukum positif terhadap masalah (kasus) tersebut. Menerapkan aturan hukum positif hanya dapat dilakuhan secara kontekstual menginterpretasikan aturan hukum tersebut untuk menemukan kaidah hukum yang tercantum di dalamnya, dalam kerangka tujuan kemasyarakatan dari pembentukan aturan hukum (teleologikal) yang dikaitkan pada asas hukum yang melandasinya dengan melibatkan juga berbagai metode interpretasi lainnya (gramatikal, historikal, sistematikal, sosiologikal). Banyak contoh kasus hukum yang menggambarkan bahwa cara penalaran hukum yang melibatkan asas hukum dan tujuan kemasyarakatan aturan hukum terkait sering diabaikan. Tidak ada Hakim atau pun Pengacara, yang mulai berargumentasi dari suatu keadaan hampa. Argumentasi hukum selalu dimulai dari hukum positif. Hukum positif bukan merupakan suatu keadaan yang tertutup ataupun statis, akan tetapi merupakan satu perkembangan yang berlanjut. Dari suatu ketentuan hukum positif, yurisprudensi akan menentukan norma-norma baru. Orang dapat bernalar dari ketentuan hukum positif dari asas yang terdapat dalam hukum positif untuk mengambil keputusan-keputusan baru.

Argumentasi hukum, adalah "alasan berupa uraian penjelasan yang diuraikan secara jelas, berupa serangkaian pernyataan secara logis, untuk memperkuat atau menolak suatu pendapat, pendirian atau gagasan, berkaitan dengan asas 
hukum, norma hukum dan peraturan hukum konkret, serta sistem hukum dan penemuan hukum".Suatu argumentasi bermakna, hanya dibangun atas dasar logika, adalah suatu "conditio sine qua non" agar suatu keputusan dapat diterima, yakni apabila didasarkan pada proses nalar, sesuai dengan sistem logika formal yang merupakan syarat mutlak dalam berargumentasi.

Menurut Soekadijo (1985: 27) kata 'logika' sebagai istilah, berarti suatu metoda atau teknik yang diciptakan untuk meneliti ketepatan penalaran. Untuk memahami logika, orang harus mempunyai pengertian yang jelas mengenai penalaran. Penalaran adalah satu bentuk pemikiran. Bentuk-bentuk pemikiran yang lain, mulai yang paling sederhana ialah pengertian atau konsep (concept), proposisi atau pernyataan (proposition, statement) dan penalaran (reasoning). Tidak ada proposisi tanpa pengertian (konsep) dan tidak ada penalaran tanpa proposisi. Untuk rnemahami penalaran, maka ketiga bentuk pemikiran harus dipahami bersama-sama. Menurut Brouwer (1982: 208), satu dalil yang kuat, satu argumentasi bermakna hanya dibangun atas dasar logika. Dengan kata lain adalah suatu "conditio sine qua non" agar suatu keputusan dapat diterima, adalah apabila didasarkan pada proses nalar, sesuai dengan sistem logika formal yang merupakan syarat mutlak dalam berargumentasi. Menurut N.E. Algra (1983: 65) argumentasi yang merupakan hasil ijtihad hakim dari pada putusan itu harus dicantumkan dengan jelas dalam pertimbangan hukumnya, dan sesuai dengan sistem penalaran hukum dalam membuat putusan. Hakim dalam membuat argumentasi pada putusannya senantiasa akan menggunakan logika formal dengan menarik kesimpulan dari premis mayor dan premis minor. Selain menarik fakta atau peristiwa hukum hakim harus mensinerjikan norma-norma hukum yang berlaku dalam masyarakat, baik dari hukum positif, hukum kebiasaan dan norma-norma hukum lainnya. Sehingga putusan tersebut akan terjadi sistimatis dan logis dan apabila di baca dapat diketahui atau difahami dengan jelas argumen-argumen atau alasan-alasannya. Dengan demikian bagi pihak yang membaca putusan tersebut akan mengerti dan memahami bahwa putusan itu mempunyai kepastian hukum, kemanfatan, seni bahasa (keindahan) dan keadilan bagi para pihak pencari keadilan. Argumentasi sebagai dasar dan cara penemuan hukum hakim atau ijtihad hakim dalam putusan tersebut adalah terdiri dari:

1. Agumentasi yuridis (Peraturan perundang-undangan dan Hukum Islam Kompilasi Hukum Islam (KHI).

2. Argumentasi Yurisprodensi

3. Argumentasi Hukum Kebiasaan atau Adat,Ushul Fiqh, Fiqh dan kaidah ushul fiqh dan lain-lain). 


\section{Islãmadìna \\ JURNAL PEMIKIRAN ISLAM}

4. Argumentasi Moral.

5. Argumentasi Sosiologis (argumentasi Nomor 4 dan Nomor 5 ini dapat dikatakan ilmu pengetahuan).

6. Argumentasi Penafsiran atau Interprestasi hukum. Adapun macam interprestasi atau penafsiran tersebut adalah: Interprestasi Gramatikal (Bahasa), Interprestasi Sistimatis, Interprestasi Historis dan Sosiologis atau Teologis, Interprestasi Komparatif, Interprestasi Antisipatif atau Futuristis, Interprestasi Restriktif, Interprestasi Ekstensif, dan Interprestasi a Contrario.

Hakim dalam merumuskan dan menyusun pertimbangan hukum harus cermat, sistimatik dan dengan bahasa Indonesia yang benar dan baik. Pertimbangan disusun dengan cermat artinya pertimbangan hukum tersebut harus lengkap berisi fakta peristiwa, fakta hukum, perumusan fakta hukum penerapan norma hukum baik dalam hukum positif, hukum kebiasaan, Yurisprodensi serta teori-teori hukum dan lai-lain, yang dipergunakan sebagai argumentasi (alasan) atau dasar hukum dalam putusan hakim tersebut. Menurut Sudikno Mertokusumo (2002: 194-195), pertimbangan hukum disusun dengan sistimatik artinya runtut mulai dari kewenangan Peradilan sampai dengan biaya perkara dibebankan seperti adalah sebagai berikut ${ }^{1}$ :

1. Pertimbangan hukum tentang kewenangan absolut

2. Pertimbangan hukum legal standimg

3. Pertimbangan dalil pokok dan cabang penggugat

4. Pertimbangan dalil jawaban pokok dan cabang tergugat mungkin dalil eksepsi dan rekonvensi:

a. Pertimbangan dalil gugatan yang harus dipertimbangkan

b. Pertimbangan dalil jawaban yang harus dipertimbangkan

c. Pertimbangan alat-alat bukti apakah memenuhi syarat formal dan materiil dan bukti tersebut diterima atau ditolak

d. Pertimbangan fakta-fakta baik fakta peristiwa maupun fakta hukum yang dapat dibuktikan

e. Pertimbangan perumusan hubungan hukum antara peristiwa hukum dengan fakta hukum yang telah dibuktikan

f. Pertimbangan perumusan hubungan antara peristiwa hukum dengan fakta hukum yang telah dikwaifikasi menjadi kebenaran berdasarkan alat bukti 
g. Pertimbangan argumentasi-argumenasi hukum baik yang berhubungan dengan hukum-hukum positif, kebiasaan, sosiologi hukum moral hukum dan lain sebagainya atau hukum yang hidup dalam masyarakat

h. Pertimbangan hukum yang berkaitan biaya perkara

i. Pertimbangan atau judgement apakah gugatan ditolak, dikabulkan atau tidak diterima.

Menurut Sudikno Mertokusumo (2002: 203), Legal reasoning atau ratio decidendi atau pertimbangan hakim adalah bagian dari putusan pengadilan Indonesia yang mempertimbangkan dasar hukum yang dipakai dalam memutuskan suatu perkara.Dalam menggunakan pendekatan kasus, apabila putusan dilihat sebagai penetapan kaidah hukum maka yang mengikat adalah pertimbangan atau alasan yang secara langsung mengenai pokok perkara, yaitu kaidah hukum merupakan dasar hukum putusan "Ratio decidendi".

Menurut Peter Mahmud Marzuki (2009: 94) untuk menemukan ratio decidendi dalam suatu putusan biasanya dapat dilihat pada bagian-bagian tertentu. Untuk sampai kepada salahsatu putusan itu hakim harus menuliskan alasan-alasannya, yaitu ratio decidendinya. Di dalam hukum Indonesia yang menganut civil law system, ratio decidendi tersebut dapat dilihat pada konsiderans "Menimbang" pada "Pokok Perkara". Ratio dapat ditemukan dengan memperhatikan fakta materiil dan putusan yang didasarkan atas fakta itu. Dengan demikian, dari suatu fakta materiil dapat terjadi dua kemungkinan putusan yang saling berlawanan. Yang menentukan adalah Ratio decidendi putusan itu. Menurut Abraham Amos HF. (2007: 34) pada umumnya fungsi Legal Reasoning adalah sebagai sarana mempresentasikan pokok-pokok pemikiran tentang problematika konflik hukum antara seseorang dengan seorang lainnya, atau antara masyarakat dengan pemerintah terhadap kasus-kasus yang menjadi kontroversi atau kontraproduktif untuk menjadi replica dan duplica percontohan terutama menyangkut baik dan buruknya system penerapan dan penegakan hukum, sikap tindak aparatur hukum dan lembaga peradilan. Putusan pengadilan atau yurisprudensi sebagai sumber hukum sangat penting artinya bagi praktik hukum. Pendekatan perundang-undangan tidak selalu memberikan pedoman dalam membangun argumentasi hukum. Dalam situasi tersebut maka untuk memperoleh kepastian tentang kaidah yang relevan dapat ditempuh dengan pendekatan kasus, yakni membangun argumentasi hukum dengan mengacu pada pendapat hukum yang dirumuskan hakim dalam sebuah putusan pengadilan.

\section{KESIMPULAN}




\section{Islãmadîna \\ JURNAL PEMIKIRAN ISLAM}

Dari keseluruhan pembahasan yang telah dilakukan di atas, maka penulis dapat menyimpulkan bahwa putusan adalah produk hakim di pengadilan. Dalam memutus perkara yang terpenting adalah kesimpulan hukum atas fakta yang terungkap dipersidangan. Seorang hakim sebelum melaksanakan tugasnya yaitu membuat putusan atas perkara yang ditanganinya, tidak boleh memutuskan begitu saja tanpa memberikan argumentasi hukum atau pertimbangan hukum atau legal reasoning, sehingga keputusan yang akan dijatuhkan dapat didasari oleh rasa tanggung jawab, keadilan, kebijaksanaan, profesionalisme dan bersifat obyektif.

Argumentasi hukum, adalah alasan berupa uraian penjelasan yang diuraikan secara jelas, berupa serangkaian pernyataan secara logis, untuk memperkuat atau menolak suatu pendapat, pendirian atau gagasan, berkaitan dengan asas hukum, norma hukum dan peraturan hukum konkret, serta sistem hukum dan penemuan hukum.Suatu argumentasi bermakna, hanya dibangun atas dasar logika, adalah suatu "conditio sine qua non" agar suatu keputusan dapat diterima, yakni apabila didasarkan pada proses nalar, sesuai dengan sistem logika formal yang merupakan syarat mutlak dalam berargumentasi. Tidak ada Hakim atau pun Pengacara, yang mulai berargumentasi dari suatu keadaan hampa. Argumentasi hukum selalu dimulai dari hukum positif. Hukum positif bukan merupakan suatu keadaan yang tertutup ataupun statis, akan tetapi merupakan satu perkembangan yang berlanjut. Dari suatu ketentuan hukum positif, yurisprudensi akan menentukan norma-norma baru. Orang dapat bernalar dari ketentuan hukum positif dari asas yang terdapat dalam hukum positif untuk mengambil keputusan-keputusan baruLegal reasoning atau argumentasi hukum atau pertimbangan hukum adalah bagian dari putusan pengadilan dalam memutuskan suatu perkara. Legal reasoning yang dilakukan oleh seorang hakim dapat berdasarkan aspek filosofis, yuridis, sosiologis atau teologis yang mencerminkan asas kepastian hukum, keadilan dan kemanfaatan bagi para pihak. Selain dasar pertimbangan tersebut, seorang hakim juga dapat menggunakan beberapa metode penafsiran hukum dalam memberikan argumentasi hukumnya seperti penafsiran Sistimatis, Historis dan Sosiologis atau Teologis, Komparatif, Antisipatif atau Futuristis, Restriktif, Ekstensif dan atauA Contrario. Legal reasoning atau pertimbangan hukum yang merupakan hasil ijtihad hakim dari pada putusan itu harus dicantumkan dengan jelas dalam pertimbangan hukumnya, dan sesuai dengan sistem penalaran hukum dalam membuat putusan.Legal reasoning atau pertimbangan hukumtersebut juga harus disusun dengan sistimatik oleh hakim,yaitudisusun secara runtut mulai dari kewenangan Peradilan sampai dengan biaya perkara yang dibebankan. 


\section{DAFTAR PUSTAKA}

Abraham, Amos HF. Legal Opinion Teoritis \& Empirisme. Jakarta: PT. Grafindo Persada, 2007.

Brouwer, P.W., A. Soeteman.Logica en Recht, WEJ. Tjeenk Willink: Zwolle, 1982.

Cik Hasan Bisri.Peradilan Agama di Indonesia, Jakarta: PT Raja Grafindo Persada, 1996.

Garner, Bryan A.Blak's Law Dictionary,Sevent Editions, St. Paul Min.: West Group, 1999.

Golding, Martin P.Legal Reasoning, New York: Alfreda A. Knoff Inc., 1984.

Harahap, M. Yahya. Hukum Acara Perdata. Jakarta: Sinar Grafika, 2005.

Khamimudin. Panduan Praktis Kiat dan Teknis Beracara di Pengadilan Agama, Yogyakarta: Gallery Ilmu, 2010.

Komisi Hukum Nasional Republik Indonesia.Laporan Akhir Rekrutmen Dan Karir Di Bidang Peradilan, Disusun Oleh Kelompok Kerja A.2 Fakultas Hukum Universitas Gadjah Mada, Yogjakarta: Fakultas Hukum UGM, 2003.

Mertokusumo, Soedikno. Hukum Acara Perdata Indonesia, Yogyakarta: Liberty, 2002.

N.E. Algra, K. van Duyvendijk. terjemah J.C.T. Simorangkir. Mula Hukum, Beberapa Bab Mengenai Hukum dan Ilmu Hukum untuk Pendidikan Hukum dalam PengantaruIlmu Hukum, Jakarta: Bina Cipta, 1983.

Peter, Mahmud Marzuki. Pengantar Ilmu Hukum. Jakarta: Kencana, 2009.

Rakhmad, Jalaluddin.Kamus Filsafat, Jakarta: Rosda Karya, 1995.

Ranuhandoko, IPM. Terminologi Hukum, Jakarta: Sinar Grafika, 1996.

Sidharta. Penalaran Hukum dalam Sudut Pandang Keluarga Sistem Hukum dan Penstudi Hukum, Bandung: Citra Aditya Bakti, 2000.

Soekadijo, RG.Logika Dasar, Tradisional; Simbolik dan Induktif. Jakarta: Gramedia, 1985.

Soeparmono, R. Hukum Acara Perdata dan Yurisprudensi. Bandung: Mandar Maju, 2005. 


\section{Islãmadîna}

JURNAL PEMIKIRAN ISLAM

Volume XVIII, No. 2, Juni 2017 : 41-56

Sudarsono, Kamus Hukum. Jakarta: Rineka Cipta, 2005.

Susanto, LS.dan Bernard L. Tanya (Ed.). Wajah Hukum di Era Reformasi: Kumpulan Karya Ilmiah Menyambut 70 Tahun Prof. Dr. Satjipto Rahardjo, S.H. Bandung: Citra Aditya Bakti, 2000.

Tim Peneliti Komisi Yudisial RI.Profesionalisme Hakim: Studi Tentang Putusan Pengadilan Tingkat Pertama dalam Perkara Perdata dan Pidana di Indonesia. Riset: Komisi Yudisial. Jakarta, 2009.

Tim Penyusun Kamus Besar Bahasa Indonesia.Kamus Besar Bahasa Indonesia, Jakarta: Media Pustaka Phonix, 2009.

UU No. 48 Tahun 2009 Tentang Kekuasaan Kehakiman

Wojowasito, S.Kamus Umum Belanda-Indonesia, Jakarta: Ichtiar Baru Van Hoeve, 2001. 